\title{
Perspective of online retailing in India
}

\author{
Shilpa Jain \\ Visiting Faculty, Institute of Management Studies, Devi Ahilya Vishwavidyalaya University, Indore, Madhya Pradesh, India
}

Corresponding Author:

Email: Shilpaj347@gmail.com

\begin{abstract}
Online retailing is a global trend which is rapidly gaining momentum in India. The study aims to estimate the challenges and opportunities of online retail business in the Indian market. A SWOT analysis has been performed from the assessment of literature review. The growing number of internet users in India provides a great opportunity for online retail market. With advent of various payment methods like net banking, mobile apps, wallet payments systems, the transaction procedures have easen up which lead to increase use of online buying channels. Cash on delivery has also entrusted customers. The key challenges are to maintain the privacy of customer personal and financial data, to have smooth logistics network, to improve reach of online market to rural customers, handling fake websites etc. Recommendations are made at the end suggesting that it is paramount for a large consumer market like India to put an effective framework which can help in leveraging the opportunities generated from online retail market space.
\end{abstract}

Keywords: Online retail industry, Challenges, Opportunities, SWOT, Online retail market.

\section{Introduction}

The retail industry globally has changed drastically over the past decade with the advent of online and digital media. In India, the retail industry accounts for over $10 \%$ of the country's Gross Domestic Product (GDP) (IBEF, 2018b). However, the online retail market has currently raised concerns with store retail market. The Indian online retail market comprises of $23 \%$ of all retail sales as in FY2017 valuing to approximately $\$ 38.5$ billion (IBEF, 2018a). Online retail is more commonly known as e-commerce. According to a report by Morgan Stanley Inc. presented by Sushma, (2017) online retail is forecasted to grow over $1,200 \%$ to $\$ 200$ billion in India by FY2026. Major online retail market players in India are Amazon, Flipkart, eBay, Snapdeal, Alibaba, PayTM and many others to name (Casanova, Cornelius, \& Dutta, 2018). However, the online market has faced and still experiencing many challenges and opportunities (Kalia, Kaur, \& Singh, 2016). However, it is also perceived by Kalia et al., (2016), that higher the penetration of internet, higher will be the sales and value market of online retail market.

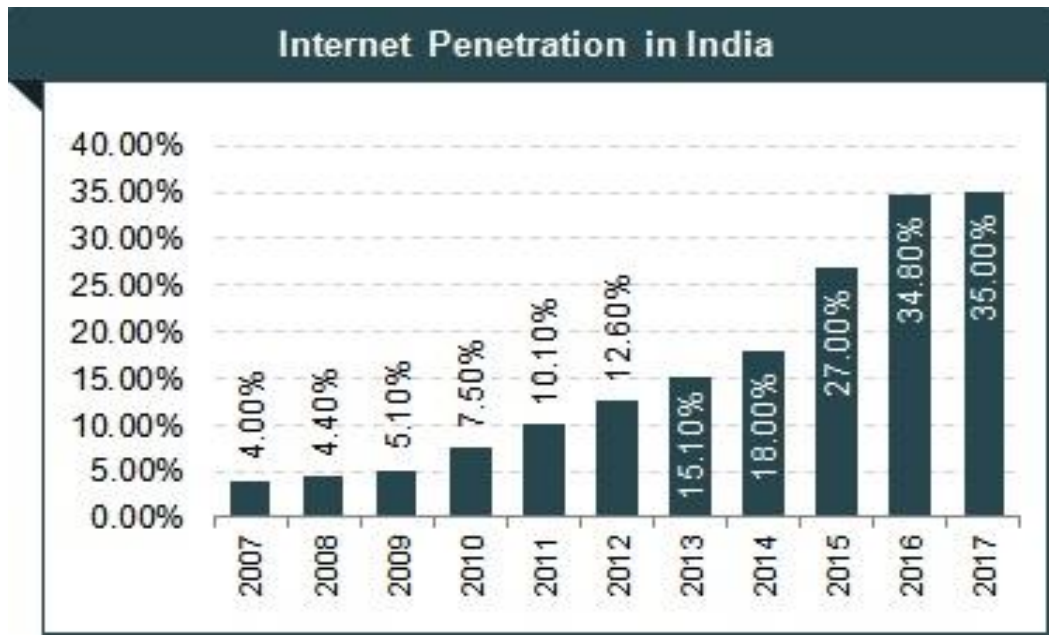

Source: (IBEF, 2018a)

Fig. 1: Rate of internet penetration (2007-2017)

\section{Literature Review \\ SWOT Analysis of Online Retailing in India}

SWOT analysis stands for Strengths, Weaknesses, Opportunities and Threats which allows analyzing the ecology of the market (Frue, 2016). In this study the SWOT analysis of the global retail market has been presented 
which is then assessed in Indian context. It helps to find out the strengths and weaknesses of online retailing business environment along with emerging opportunities and threats.

Table 1: SWOT analysis of global online retail market (Khan \& Sagar, 2015; Yadav \& Sharma, 2014)

\begin{tabular}{|ll|l|}
\hline \multicolumn{1}{|c|}{ Strengths } & \multicolumn{1}{c|}{ Weakness } \\
\hline $\begin{array}{l}\text { Exchange through web is efficient and fast. It } \\
\text { spares time by decreasing physical employment }\end{array}$ & 1 . $\begin{array}{l}\text { Data Security is a big challenge that may impact } \\
\text { online market. }\end{array}$
\end{tabular}
and activities for e-tailors.

2. $24 \times 7$ accessibility demonstrates that online retailing and exchanges can be accessed anyplace and whenever as there is no time imperative.

3. Online business gives stage to consumers to look at cost and other information effectively. It allows choosing from wide range of products and services.

4. Target market segment in internet business is adaptable and can be altered whenever.

5. Niche Market, whereby uncommon products and services are served, can be made accessible without putting some exceptional endeavors by the purchaser.

6. Discounts and offers attract mass consumers from diverse age and segment of consumers.

7. Ability to provide similar products as found at physical stores, at same or at discounted prices.

8. Availability of various payment options is there, even options like cash on delivery is also present.

\begin{tabular}{|l}
\hline \multicolumn{1}{c}{ Opportunities } \\
\hline 1. \\
$\begin{array}{l}\text { Penetration of internet users is increasing which } \\
\text { results in increase in number of purchase over } \\
\text { online services. }\end{array}$
\end{tabular}

2. Online retail market can be accessible anywhere and anytime.

3. Online retail is quick and compelling even in respect to budgetary exchanges as they can be accessed from anywhere in the world. Future and new age consumers feel more satisfied to purchase items through web.

4. High availability, which is $24 \times 7$ days.

5. Online retailing has broader vision and wider scope to flourish and grow in the volatile market.

6. Online retailing is a new and still juvenile entity in the developing nations.

7. Diverse payment options.
2. Availability of fake websites.

3. Lack of physical examination of products.

4. Creating customer's satisfaction is a big challenge.

5. Concerns about misuse of financial and personal data are present.

6. Shipping cost increases on the basis of product and distance.

7. Delivery time can be in days or weeks.

8. Wrong product delivery or delivery of damaged product may occur.

Threats

1. Local competition and global competition in the online retail market as many new startups and online retailers have come up. Even bigger brands have nowadays adhered to online accessibility of shopping products.

2. Changing rules and regulations of business environment pose a challenge to e-tailors.

3. Customers not only look for innovative products and budget but also for effective and efficient products.

4. No direct interaction between customer and the seller and no scope of bargaining.

5. Transaction may exhibit fraudulence by both the seller and purchaser.

6. Online retail market is very volatile, as consumers get satisfied on various aspects of business like quality of products, price, services and others. Poorer the perspective lower is the chance consumers will buy from the retailer in future

7. Nowadays there are many consumers who review and rate products and services provided by online retailers, which may act as a threat to other peers as the credibility of the reviewers might be questionable.

\section{Opportunities of online retail market: India}

In the recent years, retail market is evolving to new approaches because of inception and development of information technology. IT has drastically changed the retail market with the setting up of automated technologies, internet usability, smart phone 
applications and other high end electronic products, boosted by high end applications and software. India has approximately 200 million internet users and it has been predicted that this surge will rise to 500 million by end of 2018 (Pandey, 2016). Thus, this is one major opportunity for rising online retail in India. The usage of smart phone revolution has now created a new trend amongst youngsters and new age consumers to exploit its uses and application. Moreover, the usability of mobile internet has also improved extraordinarily in the recent years providing opportunity to online retailers (Das and Ara, 2015). Online transaction methods such as debit cards, online banking, credit cards, wallet payments, mobile banking apps and others have increased over the past decade giving another opportunity to online retailers. According to Pandey, (2016), the increased disposable income in India has grown at CAGR of $5.1 \%$ and urbanization has also accentuated rapidly with over $40 \%$ of the total Indian population living in urban areas which provide opportunity to online retailers. Internet penetration by far is the major opportunistic feature for online retailers. Other lucrative features of online retail include ease of comparison of the products, cash back guarantees, cash on delivery, cost and time saving, substantial discounts compared to physical retail, access to branded products and ease of delivery (Khan \& Sagar, 2015).

\section{Challenges of online retail market: India}

One of the biggest problems which impact the online retail market of India is the slow speed internet connection, especially in sub-urban and rural regions. Another problem identified by Jayakrishnan.S, (2015) for Indian online retailers is poor front ends of exiting on-line retail websites, poor optimization of website search options, lack of sufficient information, slower websites and poor traffic. Online consumers in India are very specific and demanding as they are very peculiar about their need and spent comparatively less time is searching the right product (Dwivedi et al., 2012). This challenges the online retailer in a way that if a product is not found then the customers get disappointed and land on to another competitor website. Maintenance of customer trust and loyalty is also a big challenge for the online retailers, which can be easily shaken if poor customer services are provided (Deloitte, 2014). Issues of security and transaction frauds, poor website features, inappropriate technical usability, lack of proper digital content and expensive online marketing and advertisement are a few other challenges which threaten the existence of online retailers in India (Dwivedi et al., 2012; Pandey, 2016). Other barriers of online retailing in India are fear of faulty products, inability to bargain, touch, inability to take trial of products and partial financial details of products displayed on website (Khan \& Sagar, 2015).

\section{Recommendations}

Restrictions on offering products and services via e channel should be minimal in order to drive the demand. A strong fundamental infrastructure facility like well connected roads, rail network is required to curb the logistic constraints so that people in farthest geographic regions can also be benefitted by the online retail boom. There should be a direct and easy link between manufacturers and online sellers in order to decrease the supply side irregularities. Clear taxation policies for this market should be introduced. It is also recommended that online retailers must look to build quality, attractive and high technology based websites which attract consumers and allow building of loyalty and trust. Online retailers should try to be more vigilant with security of personal and financial information of customer. Along with increasing the consumer base, online retailers have to focus on improving profitability of their business model for sustaining in present business environment.

\section{Conclusion and future scope}

The progress of online retailing is likely to provide an impetus to manufacturing sector by driving overall demand for all sorts of goods. The SME sector will get an extended market reach because of online retailing. A new class of logistics and distribution channel has also aroused because of online retail market giving employment to large number of people. This encompasses huge storage centres and godowns, parcel and delivery channels, local depots and return order processing units. The online retailing has notably disrupted the traditional Indian retail market in a positive way by decreasing the high retail costs for bricks and mortar shops and reducing skilled store level manpower. Online shopping is growing with the help of Information Technology (IT) and other technological advancements. In order to achieve further growth in this sector, an depth analysis of perspectives of customers and online retailers should be done to grab the burgeoning opportunities and tackle challenges. If provided by efficient regulatory bodies and favorable economic conditions, the sustainability of this sector can be potentially higher.

\section{References}

1. Casanova, L., Cornelius, P. K., \& Dutta, S. (2018). Flipkart and the Race to the Top of Indian e-Commerce. In Financing Entrepreneurship and Innovation in Emerging Markets (pp. 133-157). https://doi.org/10.1016/B978-0-12-804025-6.00006-X

2. Das,Kishore.,\& Ara,A. (2015).Growth of e-commerce in India.International Journal of Core Engineering and Management,2(4).

3. Deloitte, (2014). Online retail in India clicking towards growth. Deloitte Touche Tohmatsu India Pvt Ltd. Retrieved from https://www2.deloitte.com/in/en/pages/consumerbusiness/articles/online-retail-in-india.html

4. Dwivedi, M., Mahesh, K., \& Sanjeev, V. (2012). On-Line 
Retailing in India : Opportunities and Challenges. International Journal of Engineering and Management Sciences, 3(3), 336-338.

5. Frue, K. (2016). What is the use of SWOT analysis? Retrieved from http://pestleanalysis.com/what-is-the-useof-swot-analysis/\%5Cninternal-pdf://0.0.0.224/what-isthe-use-of-swot-analysis.html

6. IBEF. (2018a). E-commerce Industry in India. Retrieved from https://www.ibef.org/industry/ecommerce.aspx

7. IBEF. (2018b). Retail industry in india. Retrieved from https://www.ibef.org/industry/retail-india.aspx

8. Kalia, P., Kaur, N., \& Singh, T. (2016). E-Commerce in India: Evolution and Revolution of Online Retail. In $E$ Retailing Challenges and Opportunities in the Global Marketplace (pp. 99-120). https://doi.org/http://dx.doi.org/10.4018/978-1-46669921-2.ch005

9. Khan, M. A., \& Sagar, P. (2015). Emerging Trends and Advanced Swot Analysis of E-Commerce in Indian Context. International Journal of Science Technology \& Management, 4(2), 150-159. Retrieved from https://www.ijstm.com/images/short_pdf/M027.pdf

10. Khare, A., Khare, A., \& Singh, S. (2012). Attracting Shoppers to Shop Online-Challenges and Opportunities for the Indian Retail Sector. Journal of Internet Commerce, 11(2), 161-185.

https://doi.org/10.1080/15332861.2012.689570

11. Pandey, V. (2016). E-retailing: Challenges and Opportunities in India. International Journal of Development Research, 6(12), 10823-10828.

12. S, Jayakrishnana.(2015).E-retailing in India. International Journal of Finance and Marketing.5(3).

13. Sushma, U. N. (2017). Morgan Stanley explains why India's e-commerce market is a hot investment opportunity. Retrieved from https://qz.com/1089559/morgan-stanley-explains-whyindias-e-commerce-market-is-a-hot-investmentopportunity/

14. Yadav, M. K., \& Sharma, D. (2014). SWOT Analysis of E-Commerce. Advance in Electronic and Electric Engineering, 4(6), 663-668. 